\title{
DOING INSTITUTIONS. \\ A DIALECTIC READING OF INSTITUTIONS AND SOCIAL PRACTICES AND ITS RELEVANCE FOR DEVELOPMENT GEOGRAPHY
}

\author{
Benjamin Etzold, Sebastian Jülich, Markus Keck, \\ Patrick Sakdapolrak, Thomas SchmitT and Anna Zimmer
}

With 1 figure

Received 11. May 2011 · Accepted 17. July 2012

\begin{abstract}
Summary: Twelve years after the discussions on development and institutions at the meeting of the Geographischer Arbeitskreis Entwicklungstheorien (GAE 2000) in Zürich, this paper seeks to put institutions back on the research agenda in development geography. The authors explore recent trends in institutional theory and propose a dialectic understanding of "doing institutions" that positions social actors and their everyday practices at the center of institutional analysis. Institutions are the socially (re-)produced rules that enable, constrain and give meaning to the social practices of actors. Actors make institutions; at the same time institutions make actors do certain things. Based on this foundation, three central aspects of the institutional debate are elaborated: Institutional plurality, the legitimacy of institutions, and the role of the state. Two case studies from recent research in South Asia illustrate aspects of the conceptual considerations. The article ends with an outlook on the implications of "doing institutions" for future research in development geography.
\end{abstract}

Zusammenfassung: Zwölf Jahre nachdem das Verhältnis zwischen Entwicklung und Institutionen beim Geographischen Arbeitskreis Entwicklungstheorien (GAE 2000) in Zürich debattiert wurde, ist es Ziel dieses Beitrags, das Thema Institutionen wieder auf die Agenda geographischer Entwicklungsforschung zu setzen. Verschiedene Institutionentheorien werden beleuchtet, um ein dialektisches Verständnis des „Institutionen-Machens“ zu entwickeln, in dem soziale Akteure und ihre alltäglichen Praktiken im Zentrum der Analyse stehen. Menschen machen Institutionen und gleichzeitig strukturieren Institutionen menschliches Handeln. Wir definieren Institutionen daher als sozial (re)produzierte Regeln, welche die alltäglichen Praktiken von Akteuren ermöglichen, beschränken und ihnen eine Bedeutung zuweisen. Drei zentrale Aspekte der Institutionendebatte werden aufgeworfen: die Pluralität von institutionellen Regelungen, die Legitimität von Institutionen sowie die Rolle des Staates. Das entwickelte Verständnis von Institutionen und sozialer Praxis wird anhand von zwei Fallstudien aus Südasien illustriert. Der Beitrag schließt mit einem Ausblick auf mögliche zukünftige Forschungsfelder der Geographischen Entwicklungsforschung.

Keywords: Institutions, neo-institutional theory, social practices, development geography, South Asia

\section{Introduction: The institutional debate in development geography}

It goes without saying that laws, rules, social norms, values and shared cognitive systems are fundamental aspects of human behavior. But surprisingly, institutional theory that concentrates on these issues plays only a shadowy existence in the conceptual discussions in human geography. The standard German geography textbook (GEBHARDT et al. 2011), for instance, hardly mentions the term institutions and disregards institutional theory completely. While it is quite common to borrow key concepts from the adjoining social sciences, such as social systems, agency, interactions or discourses, the explicit study of institutions has received very little attention in German-speaking social geography (cf. WeichHart 2008, 333). Of all geographical sub-disciplines, the study of institutions is probably most firmly established in economic geography (cf. Schamp 2000; Bathelt and GlüCKLer 2003), where the scholars from the new institutional economics (cf. Williamson 1975; North 1990) were acknowledged. Despite this, numerous human geographers have continuously carried out research on and about institutions in recent decades. And yet, their empirical studies have rarely focused on institutions as such, but implicitly pointed to the importance of analyzing institutions in order to understand the social world. 
In development geography, research on institutions is grounded in the famous work of AMARTYA SEN (1981) on food entitlements. SEN perceived institutions as mostly state-set rules that effectively grant - or deny - actors' access to needed resources, such as food, finances or services. SEN pointed out that entitlement failure is an important factor explaining hunger and famine (cf. WATTS and BoHLE 1993). At the meeting of the Geographischer Arbeitskreis Entwicklungstheorien (GAE) 2000 in Zürich (see special issue of Geographica Helvetica edited by MülLER-BöKer 2001), implications of institutional theory for research in development geography were discussed with an explicit focus on new institutional economics (NIE). Based on the work of Douglass North (1990, 3), institutions were defined as the "rules of the game in a society, or, more formally [...] the humanly devised constrains that shape human action". Compared to SEN, North broadened the understanding of institutions by incorporating informal rules, such as norms, habits, attitudes and beliefs into his conceptualization, which provided some common ground for works in development geography (HARRISS et al. 1995; LeACH et al. 1999; BÜtTNER 2001; COY 2001; MÜller-BöKer 2001; ThOMI 2001; Krüger 2003; De HaAn and Zoomers 2005; Fünfgeld 2007; Noe 2007D; Etzold et al. 2009).

Twelve years after the meeting of the GAE, we would like to take up the debate again and put institutions back on the agenda. Inspired by sociological neo-institutionalism (KNEER 2008; SCOTT 2008; Walgenbach and Meyer 2008), we would like to highlight the complex dynamics of institutions and their assertiveness and, more generally, the ambivalent processes of ordering societies. As KNEER (2008, 125ff.) puts it, institutions are permanently formed, sustained and re-negotiated in the tension between the ordered and the unordered. From such a perspective, there is a need for elaborating an actor-oriented understanding of institutions, which is the central aim of this article. We define institutions and discuss the dialectic relation of actors' practices and institutions. On this basis we elaborate three major implications of our understanding of "doing institutions": Institutional plurality and the notion of institutional bricolage, the question of the legitimacy of institutions, and the role of the state. Two case studies from our research in South Asia help to further illustrate our considerations. The article ends with suggestions for future emphasis in institutional research in development geography.

\section{The three pillars of institutions}

Broadly speaking, the institutional debate in the social sciences oscillates between a narrow understanding of institutions as "rules for action which are decisive, binding and permanent" (SENGE and Hellmann 2006, 44) and much wider conceptualizations of institutions as habitualized social practices. Our actor-oriented understanding of institutions has been largely informed by the social theories of Anthony Giddens (1984) and Pierre Bourdieu (1998), by sociological neo-institutionalism (cf. SCOTt 2008), as well as by CLEAVER's (2002) concept of institutional bricolage. We define institutions as permanently socially (re-)produced rules that enable, constrain, and give meaning to social practices and that comprise regulative, normative, and cultural-cognitive elements (cf. GIDDENS 1984; Searle 1995; Hasse and Krücken 2005; Florian 2006; SСотт 2008).

Three major institutional pillars were analytically distinguished by SсотT (2008, 48ff.). Institutions in a first and narrow sense comprise sets of more or less codified rules, decision-making procedures, and monitoring and sanctioning mechanisms that together guide human conduct. Such an understanding of institutions centers on the notion of "regulative rules" (Sсотт 2008, 52).

As addressed by SCOTT's second pillar, institutions also constitute normative systems: "Values are conceptions of the preferred or the desirable [...]. Norms specify how things should be done; they define legitimate means to pursue valued ends" (SCOTT $2008,54 f$.). Together values and norms help to define the objectives of actors and the appropriate ways to achieve them. Moreover, norms decide upon actors' social roles, their obligations and privileges (SCOTT 2008, 55), and their power position in various "fields" of society (BOURDIEU and WACQUANT 1992).

SсотT's (2008) third pillar, the "cultural-cognitive" element of institutions, works at the deepest level of society. While human cognition mediates between the external world and actors' symbolic representations of and ascription to it, the very elements of representations - symbols such as words, signs or gestures - are socially constructed. As "constitutive rules" (SEARLE 1995, 43ff.), these symbolic systems help actors to break down the reality into comprehensible categories, which make sense and which can then be translated into appropriate social practices. These deeply embedded cultural "frames" (cf. Goffman 1974) are collectively shared in a so- 
cial group and most often simply taken for granted. Inadvertently, they shape the meaning that actors assign to objects, practices and places as well as to their own identities. Capturing this cultural-cognitive dimension of institutions requires the inclusion of emotional facts such as confusion and disorientation or confidence and certitude into institutional analysis (SсOTT 2008, 59).

\section{3 "Doing institutions" - a dialectic relation of institutions and social practices}

The fact that institutions typically portray a high degree of invariance over a long time and usually outlast the life span of individuals provided social scientists a reason for choosing institutions rather than individuals as basic research units (GIDDENS 1984, 61). Nevertheless, a pure focus on institutions bears the risk of getting trapped in an extreme form of cultural or structural determinism (HodGson 1998, 181). The "methodological individualism", in turn, focuses on atomized actors as research units that are treated as taken for granted. The single focus on individuals, however, bears the risk of an exposed voluntarism (BATHelt and GlüCKLER 2003, 24). Just as institutions cannot be adequately explained by looking at the behavior of individuals, their conduct cannot be explained only through an institutional lens. Instead, both actors' practices and institutions have to be conceptualized in an interrelated manner (HODGSON 1998, 176). Institutions are dead unless they are continually "brought to life" (Berger and LuCKMAnN 1967, 75) by actors. Similarly, actors, their manifold social roles and their practices in the course of everyday life are themselves realizations of broader institutions (GIDDENS 1984, 25).

Given the interrelation between institutions and actors, how can social practices be conceptualized? With MeYer et al. (1987, 13), human conduct is nothing but actors' "enactment of broad institutional scripts". Nevertheless, actors do not follow such scripts in a blind manner, but have a potential to choose between a multitude of such scripts. JEPPERSON $(1991,148)$ puts it that way: "[O]ne enacts institutions; one takes action by departing from them, not by participating in them". However, it goes without question that actors can never reach a space that is free of institutions. In fact, actors are able to choose from alternatives and to intervene into the state of affairs not despite of but because they are institutionally embedded (Walgenbach and Meyer 2008, 121). At the same time, they find themselves involved in so- cial spaces that are constituted by broad sets of rules, norms, obligations and meanings that need to be reinterpreted constantly. This interpretation, which relies on actors' skills and knowledge, or in Bourdieu's (1998) words their capital and habitus, is a genuine activity inasmuch as each situation must be defined in a way that makes a specific institution viable and proper (Walgenbach and Meyer 2008, 174).

We define social practices as routines and strategies that are socially embedded, contingent and meaningful and thus structured by institutions (Bourdieu 1998; Florian 2006; Everts et al. 2011). In turn, actors interpret and navigate through existing societal orderings and thereby reproduce some, but never all prevalent institutions that are "in place". Social practices thus (re)structure institutions. We therefore speak of "doing institutions" in order to highlight the dialectic relation between institutions and social practices: Institutions are a medium and outcome of social practices, while social practices are a medium and outcome of institutions. We argue that such a dialectic interpretation helps us to handle the messiness and fussiness of social reality that we encounter in everyday life (not only) in the Global South.

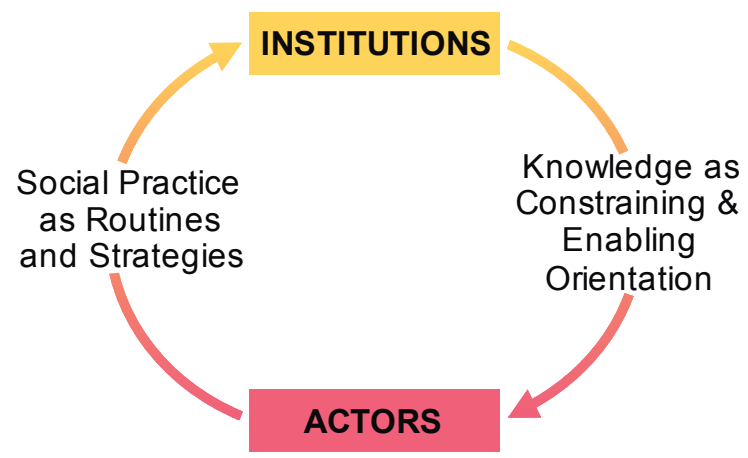

Fig. 1: Relation between actors and institutions. Source: draft KeCK 2012, based on Hodgson 1998; GidDENS 1984

\section{Conceptual implications of "doing institu- tions"}

The dialectic understanding of institutions and social practices that underlies our idea of "doing institutions" has further conceptual implications. In the following section we will highlight three crucial aspects of "doing institutions" to be considered for further discussion: Institutional plurality, the legitimacy and assertiveness of institutions, and the role of the state. 


\subsection{Institutional plurality, coexistence and brico- lage}

In the New Institutional Economics, a plurality of institutional orders has been largely discussed on the basis of the distinction between formal and informal institutions. According to NORTH (1990, 43ff.), formal institutions comprise codified and written rules, directives and contracts that are outlined in constitutions, laws, company directives or contracts. In contrast, informal institutions subsume cultural norms, customs and routines. While the former stresses SCOTT's regulative pillar, the latter emphasizes the normative and cultural-cognitive one. Pluralism in form of the formality-informality nexus is often conceptualized as the parallel existence of two sets of rules guiding actors' conduct. The distinction between formal and informal regulation of employment relations, services, markets or space is a case in point (cf. Revilla Diez et al. 2008; Etzold et al. 2009; Hossain 2011; KeCK 2012; KeCK et al. 2012).

Institutional plurality is often considered as problematic and dysfunctional because of the potential uncertainties, injustices and conflicts that result from their ambiguity (cf. Neuburger 2001; KRÜGER 2003; Young et al. 2005). An understanding of institutions that focuses on actors and their agency facilitates a more elaborated view on institutional plurality. Westermann (2007, 66) draws attention to the ability of actors to consciously choose between those coexisting legal and normative institutions that help them to pursue their goals. Cleaver's (2002) concept of "institutional bricolage" goes even one step further. Bricolage involves an active assemblage of existing rules, norms, and values by the bricoleur to suit new purposes. Bricoleurs can not only play with coexisting institutions, but actively transfer, creatively reassemble and purposely re-design them. As some bricoleurs possess more resources and social power than others, bricolage is a distinctively authoritative process. Actors with different attributes (resources, power, identities, interests, etc.) are thus likely to apply their agency in differing ways, which in turn results in a rich diversity of institutional arrangements, and which creates opportunities and spaces for negotiation (CLEAVER 2002, 28). However, the power to creatively reassemble institutional settings is highly unequally distributed within a society (Cleaver 2000, 2007). For the majority of actors particularly the subordinate - the constraining elements of institutions are much stronger than their power to reshape them.

\subsection{The legitimacy and assertiveness of institu- tions}

It is important not to limit institutional analyses to the "problem of interplay" (Young et al. $2005,60 \mathrm{ff}$.) between a plurality of coexisting institutions with possibly different functions, but rather to extend it towards the ways in which institutions are advocated, legitimized and enforced, and thus "brought to life" (BERGER and LuCKMANn 1967, 75) through social practices. The first crucial aspect is then the legitimacy of institutions, which are often simultaneously "in place", but put "into effect" to a very different degree (cf. ETzOLD et al. 2009).

Legitimacy is understood as a symbolic value that can be obtained by individual actors or organizations, and which is measured in the degree of approval, consent and support by others. The legitimacy and assertiveness of institutions does not merely depend on coercion, but largely rests on how rules are underscored by social norms and how they are framed by underlying cognitive systems. Each of SCOTT's $(2008,48)$ three pillars of institutions (regulative, normative and culturalcognitive), therefore provide a distinct basis for legitimacy, but each is insufficient, if standing alone: Conformity with legal rules and other formal directives only makes sense if these rules are underpinned by internalized norms and values, which provide "a deeper, moral base assessing legitimacy" (Sсотт 2008, 61). In cultural-cognitive terms, legitimacy stems from a common definition of a situation or a shared understanding of actors' social roles (ibid.).

As indicated, institutions require constant recognition, re-affirmation, re-investment and renegotiation in order to persist. On the one hand, they require actors and organizations that put them in effect and enforce them, and who control and possibly sanction other actors' conduct. The legitimacy of an institution thus largely depends on the legitimacy of its advocating actors. The basis of actors' legitimacy is the possession of authoritative resources such as wealth, specialist knowledge, an official position, personal characteristics like eloquence or honesty, and most importantly social recognition and prestige (Bourdieu 1998, 108; Cleaver 2002, 19). On the other hand, institutions require actors who believe in them, and who judge them as relevant, appropriate, practicable, durable and fair (FLORIAN 2006, 85; SCOTt 2008, 59f.). Dominant sets of institutions are often perceived as self-evident, 
natural, inevitable or indisputable, in particular by those actors with little power to change them (Bourdieu and Wacquant 1992, 98; Scott 2008, 58). As actors internalize dominant norms, values and beliefs into their own perceptions, expectations and aptitudes, most actors act in accordance with dominant institutions and do not question their legitimacy.

\subsection{Institutions and the everyday state}

Institutions distribute power among social groups (cf. Hall and TAYLOR 1996). It is self-evident then that the relation between institutions and the nation state needs to be addressed too. The relations between institutions and the state are mostly discussed with regard to the "regulative pillar" of Sсотт's institutional trinity. The state is considered as the major rule-making actor and it is assumed that it behaves in a neutral way in enforcing them (Bourdieu 1998, 35ff.; LEACH et al. 1999, 238). Deviations from state sanctioned institutions are considered as exceptions and failures (CLEAVER 2002 , 14). However, the role of the state at a normative and especially cultural-cognitive level should not be overlooked. As Bourdieu (1998, 2006) points out, the concentration of symbolic capital, i.e., any attribute that is valued by actors, has a significant role for the state. By monopolizing symbolic capital, the state has the authority to judge what can be, and what has a legal right to exist. The power of the state enables it to define specific categories of persons, to set the rules and regulations applying to them, and to teach this way of thinking to its citizens and the state representatives.

What does our notion of "doing institutions" mean for the relationship between the state and institutions? While the state plays a major role in creating institutions through its apparatuses, it is important to note that the state never speaks with one voice alone. Quite contrastingly, looking at institutions as a plurality of shifting rules, norms and cognitive patterns sheds light upon the fact that state regulations are all but alone in shaping human behavior (LeACH et al. 1999, 237; ZiMMER 2012, 254). As individual bricoleurs, state actors may create other sets of institutions in their sphere of influence, or reinterpret and selectively enforce formal institutions for their own purposes (CleAver 2002; Bourdieu 2006). Fuller and BÉnéï (2001) have been looking into this problem under the label of the "everyday state". Based on their con- cept, Corbridge et al. $(2005,5)$ suggest that the routine state is made up of "everyday institutions". Government actors and their behavior are thus embedded in two ways: On the one hand, they are integrated into their administrative hierarchy and political networks; on the other hand, they also belong to a specific local society (CLEAVER 2002, 17; CORBRIDGE et al. 2005, 152). What state representatives actually do therefore does not necessarily refer to any formal regulations, but rather to institutions built on daily routines (Brass 1997, 279; Cleaver 2002, 16; Coelho 2005, 179; Etzold 2012). The way institutions are created and put into practice by "the" state can hence shift from one situation to another (KNEER 2008, 129). In this situation of overlap and complexity, everyday rules, norms and cognitive patterns are "constantly negotiated, contested and struggled over" (BoHLE et al. 2009, 54). By focusing on individual actors and their interactions, these negotiation processes become visible. The state, understood as an everyday state, becomes something people maintain intimate, personal relationships with (Osella and Osella 2001, 157). Looking at the social relations between state representatives and citizens is therefore one crucial element of institutional analysis.

\section{5 "Doing institutions" in development geog- raphy - case studies from South Asia}

Empirical research in development geography seeks to understand and explain complex social transformation processes and how they manifest themselves in social structures, in space and in the lives of people - mainly but not only - in the countries of the Global South (cf. Bohle 2011; MülLERMahn and Verne 2010). One of the research foci is to comprehend the multiple vulnerabilities of marginalized social groups, whose access to vital resources is endangered and contested (cf. BoHLE 2005; De HaAn and Zoomers 2005). Our concept of "doing institutions" serves this aim by looking at power relations and the institutional orders in arenas, which are social and thus institutionalized spaces that are realized in physical space (cf. ETzOLD et al. 2009; SAKDAPOLRAK 2010; KeCK 2012). In these arenas, the access to space, the access to resources and the access to power is often highly contested, forcing the vulnerable to play out their adaptive capacities in order to sustain their livelihoods. Two case studies from our empirical research in South Asia will help to illustrate this approach. 


\subsection{Case study 1: Slums as arenas of struggle in Delhi, India}

The case study from Delhi, India, illustrates how the megacity's slums are subject to shifting rules, values and cognitive patterns, which decisively structure their existence, their legal status and the future prospects of slum residents. ${ }^{1)}$ The sheer existence of slums already points to several competing institutions within as well as outside the state apparatus. Slums are defined by a majority within the state as illegal encroachments and a whole set of formal rules is supposed to ensure their disappearance and prevent their re-appearance (DUPONT and RAMANATHAN 2008; Ghertner 2010). Moreover, slums are depicted as temporary settlements, although they often are the homes of generations of urban citizens. Therefore, moral norms are mobilized in order to declare slums as unacceptable areas which are "unfit for human habitation" (The Slum Areas (Improvement and Clearance) Act, Government of India 1956). Yet, several rules, norms and cognitive patterns act in favor of the persistence of slums in India. Academia as well as activists argue that slums are "here to stay", thereby trying to influence people's perceptions about these settlements. Moral norms of "assistance to the poor" and "guilt of the rich", who want cheap servant labor in their homes but do not provide sufficient affordable housing options in the vicinity, imply a necessary tolerance of slums. Moreover, slum inhabitants are very often issued voter cards so that their political representatives (benefiting from the extra vote bank) feel obliged to assist (Zimmer 2009).

The plurality of institutions applying to slums is even reflected in the formal rules and the way they are interpreted by state representatives themselves. Politicians in Delhi cite the Municipal Corporations' Act to justify why they are providing slums with basic facilities and decry that the government is not following its own rules. The administration, in turn, tolerates that politicians provide infrastructure for their voters in slums through the backdoor: Politicians formally apply for the execution of infrastructure improvements through their funds, but omit where exactly in their constituency those improvements will be done. This way, formal permission is achieved to use their funds in slum areas, too. But what is seen

1) The research project on waste water governance in Delhi's slums and unauthorised colonies was conducted by Anna Zimmer from 2007-2011 under supervision of Prof. H.-G. BoHLE (University of Bonn). The project was funded by the Heinrich-Boell-Foundation. as democratic accountability by some is decried as illegal and corrupt by those objecting slums. In order to abolish slums, actors within and outside the state have created new cognitive patterns, such as the image of Delhi as a world-class city (JERVIS READ 2010), and new moral norms that are more coherent with the bourgeois environmentalism of Delhi's middle classes (BAVISKar 2003; GHerTner 2010). As a consequence, new rules are created through court judgments that even declare the provision of resettlement plots to be like "giving a reward to a pickpocket" (Dupont and Ramanathan 2008, 329).

The contestations of slums in Delhi are thus manifold and the outcomes very fragmented. While some slums are being demolished without much ado, in others slum dwellers get access to electricity, water and sewage systems and manage to hold on to the land for decades. Other slums are awarded the status of "listed", but facilities do not follow. Or water pipes are installed, but without guarantee of water flowing in them (ANAND 2011). The institutional reality regarding the existence of slums and the provision of public services in them can thus not be described by a fixed set of formal institutions that apply to them, but rather by the successes or failures of state and non-state actors in navigating through the multiplicity of institutions and benefiting from or being excluded through the gaps between them.

\subsection{Case study 2: Contested public spaces in Dhaka, Bangladesh}

The case study on street food vending in Dhaka, Bangladesh, questions the practicability of formal institutions in street food vending and illustrates how regulators of public spaces are playing with the implementation of formal rules. ${ }^{2)}$ Street food vending is omnipresent in Dhaka and plays a crucial role for the urban food supply. It is estimated that around 95,000 street food vendors appropriate public spaces in order to provide their services to the urban population and to sustain their own livelihoods (KECK et al. 2008; Etzold et al. 2009). Access to urban public space is thus a crucial livelihood resource for the ur-

\footnotetext{
2) The study of street food vending conducted by BENJAMIN ETzOLD was part of a research project on the "Megaurban Food System of Dhaka" (2007-2010) led by Prof. BoHLE (University of Bonn) and Dr. ZINGEL (University of Heidelberg, South Asia Institute) within the German Research Foundation's programme "Megacities-Megachallenge: Informal Dynamics of Global Change" (SPP 1233).
} 
ban poor (HACKENBROCH et al. 2009; ETZOLD 2011). But the magnitude of street food vending stands in stark contrast to the regulative rules of the state over the use of Dhaka's public spaces. While the unlicensed sale of prepared food in public places is prohibited by law (Dhaka City Corporation Ordinance 1983), it is in fact impossible to obtain a formal license for selling food on Dhaka's streets. As virtually none are registered, all street vendors encroach on public spaces illegally. But why then has street food vending been largely tolerated by Dhaka's authorities for decades? The existence of street food vending highlights a situation, in which not all actors have internalized the existing regulative rules. Although the city's elite normatively labels street food vending as unhygienic, backward and an illicit aspect of urban life, the logic of the strict prohibition of street food vending does not make sense to most of the city dwellers. The formal rules on street vending are thus not seen as legitimate and followed only if state representatives such as police or guards are present and use coercive means to enforce them (ETZOLD 2012).

Moreover, state actors are not solely part of the state apparatus that ought to enforce the formal regulatory framework. They are socially embedded actors and involved in the very local "politics of the street" (ВАYAT 1997). The regulation of the public space in front of Dhaka's Medical College Hospital through a security guard illustrates the implication of actors' multiple embeddedness: The main duty of the guard is to check the entrance of patients, their relatives and medical clerks, and to keep the entry gates of the hospital clear of street vendors. An interview with one of the guards revealed that he feels that he has to handle the street vendors flexibly. During the daytime when his superiors, in particular the director, are present he fulfills his duties more thoroughly. In the evening, in contrast, when his superiors have left the scene, he asserts that the vendors do not create any problems and largely tolerates their vending activities right at the hospital's main gate (ETzOLD et al. 2009). He legitimizes his own deviant behavior from his formal role by referring to the street vendors as poor city dwellers who need to sustain their livelihoods somehow. Whenever he can, he turns a blind eye to the street vendors not only because of strong social norms that imply responsibility towards the urban poor, but also because he, being a public employee at the bottom of the state hierarchy, largely shares with them the same life world and value system. It is therefore easy for him to imagine their precarious situation.
This example shows that we can only understand the different spatial and temporal patterns of the use of public spaces in Dhaka, if we analyze the real effects of institutions as they are implemented and experienced on the ground. In this regard, discerning the ways in which authoritative actors - understood as bricoleurs - play with institutional settings are highly important.

\subsection{Discussion of the case studies}

The two case studies illustrate how different aspects of our dialectic reading of "doing institution" enhances the understanding of the lives of people at risk in countries of the Global South. Starting point of both case studies are formal rules of the state regulating the appropriation and use of urban space. Both studies show that formal rules are usually not effective in a universalistic way throughout a state's territory. Instead the implementation and enforcement of state rules are highly context-specific. This is due to factors emphasized in our conception of "doing institutions".

Institutions not only comprise regulative elements, but also a normative and a cultural cognitive dimension. As such, the existence of slum settlements in Delhi, India, is not only determined by the city's Municipal Corporations' Act, but is also a question of norms (e.g., empathy, guilt or greed) through which the exception to rules are legitimized. From this perspective, contradictory and even conflictive rules can be in place simultaneously, whereas not all can become effective at once at a time. Our case study illustrates that obtaining public services in a context of shifting rules, values and cognitive patterns requires skillful navigation through an institutional jungle.

"Doing institutions" points to the importance of the need to decipher temporal and spatial dynamics of the rules of the game. The changing modes of regulation of street food vending in front of Dhaka's Medical College Hospital during the course of one day is a case in point. These dynamics can only be revealed and comprehended by putting the focus on actors and their embeddedness in relational webs of power. As has been formulated by WESTERMANN $(2007,66)$, actors not only have the ability to choose between co-existing institutions and frames of reference, but also to strategically apply them to pursue their goals. As such, street food vendors' access to public space in Dhaka, Bangladesh, is a question of governance and a multiplicity of rights and obliga- 
tions. For example, the hospital guards are part of bureaucratic structures of the state, informal street politics, socio-economic class etc. The example shows that actors bring operative rules in effect at particular places at specific times, and that the validity and practicability of institutions is subject to different interpretations and negotiations.

The case studies have underlined once more the role of the state as authority for setting rules and for distributing resources, which has deep consequences for the livelihoods of vulnerable urban populations. Our concept enhances the understanding of the assertiveness of governmental rules. It offers a conceptual entry point for analyzing the multitude of actualizations of state power in the everyday life of urban citizens (KorfF and Rothruss 2009), by shifting the focus from the state as a monolithic apparatus toward as more disaggregated view. Emphasizing the constant reinterpretation and selective enforcement of rules by the state actors, everyday deviations from formal rules can be explained.

To sum up, our understanding of "doing institutions" puts great emphasis on a broad notion of institutions and moves social actors and their practices to the center of institutional analysis and accentuates the comprehension of the dialectic relation between institutions and social practices.

\section{Going ahead in institutional research in de- velopment geography}

The elaboration of "doing institutions" has taken up and put forward several threads of discussion within human geography, in general, and development geography, in particular. We want to highlight three aspects for further consideration.

Firstly, the ideas on "doing institutions" need to be read within the ongoing debate on the relation between structure and agency. Following Dörfler et al.'s (2003) critique of a development geography that overemphasizes the agency of actors, this article emphasizes the role that institutions play for human agency. Institutions are produced and reproduced through the social practices of actors with different capacities to influence those crucial rule-making processes which decides upon their access to goods and services, and which therefore structures their "social space of vulnerability" (WATTS and BoHLE 1993). The chosen approach is sensitive to the political struggles taking place over the right social order and helps to dissect how the "hidden mechanisms of power" (BOURDIEU and WACQUANT 1992) manifest themselves in the specific social practices of actors at particular places (SAKDAPOLRAK 2010). Hence, we address one of the fundamental goals of social geography (WERLEN 1997, 65).

Secondly, "doing institutions" can take forward the analysis of governance (cf. Sснмітт 2011). "Getting institutions right" (RODRIK 2004, 10) is considered to be a crucial part of effective governance structures. Yet, the elaborations in this article point out that institutions are not static structures that can be easily technically designed (CLEAVER 2002 , 14). Rather, actors negotiate their relationship with institutions, and the state only accounts for part of the rules, values and cognitive patterns that actors refer to in their actual social practices. A view on institutions that fails to address their multidimensional, processual and fluid character has been shown to be inadequate to capture the politics and power relations inherent in the reality of everyday life. Focusing on "doing institutions", in contrast, allows an analysis of governance that directly takes power on board (Zimmer 2012; Etzold 2011; Schmitт 2011). At the same time, it shows that governance processes take place in a multitude of arenas. Governance analysis should therefore not be reduced to an investigation of, for instance, formal policies at the supranational, the national or the city level, but rather include the very local contestations of institutional orders, too. With such an understanding, we suggest, bridges can be built to the study of discourses (cf. Glasze and MatTisseK 2009), governmentality (cf. Foucault 1991; Watts 2003) and the everyday state (cf. Corbridge et al. 2005; DeAn 2010).

Last but not least, it has become clear from our case studies that space crucially matters in the discussion of institutions. As institutions seek to order social practices of actors and these actors' bodies are (still) largely bound in space, institutions often explicitly refer to a specific level on the spatial scale: From the globe, the region, the nation-state and the city to the level of the factory, the neighborhood, or the household. Institutions set the boundaries of distinct spaces; institutions determine the ownership, access to and the appropriate use of these spaces; institutions regulate the relations between different places and the flows across different spatial levels; and the symbolic value or meaning of a particular place is also ascribed through institutions (cf. WATTS 2003; EverTs et al. 2011). Actors can therefore never reach a space that is completely free from regulative rules, social norms or cognitive orderings. In turn, each arena or "governable space" (WATTS 2003, 15) has its own history, its own logic, its power rela- 
tions and its institutional order that can be contested through actors' everyday social practices. As "the geography of the world is not a product of nature but a product of the struggles between competing authorities over the power to organize, occupy, and administer space" (Ó TuAthail 1996, 1), (development) geography is also about institutions, how they distribute and legitimize power, and how institutions are (re-)produced through human agency.

\section{Acknowledgements}

We would like to thank Hans-Georg Bohle, Ulrike Müller-Böker and two anonymous reviewers for their valuable and critical comments. We also thank Jonas Hermsen for his engagement and ideas.

\section{References}

ANAND, N. (2011): Toward an anthropology of water in Mumbai's settlements. In: CLARK-DECES, I. (ed.): The Blackwell Companion to the anthropology of India. Malden.

Bathelt, H. and GlüCKLER, J. (2003): Wirtschaftsgeographie. Ökonomische Beziehungen in räumlicher Per-spektive. Stuttgart.

BAVISKAR, A. (2003): Between violence and desire: space, power and identity in the making of metropolitan Delhi. In: International Social Science Journal 55 (1), 89-98. DOI: 10.1111/1468-2451.5501009

BAYAT, A. (1997): Street politics: poor people's movements in Iran. New York.

Berger, P. and Luckmann, T. (1967): The social construction of reality. A treatise in the sociology of knowledge. New York.

BoHLe, H.-G. (2005): Soziales oder unsoziales Kapital? Das Sozialkapital-Konzept in der Geographischen Verwundbarkeitsforschung. In: Geographische Zeitschrift 93 (2), 65-81.

- $\left(2011^{2}\right)$ : Vom Raum zum Menschen: Geographische Entwicklungsforschung als Handlungswissenschaft. In: Gebhardt, H.; Glaser, R.; Radtke, U. and Reuber, P. (eds.): Geographie. Physische Geographie und Humangeographie. Heidelberg, 746-763.

Bohle, H.-G.; Etzold, B.; Keck, M. and Sakdapolrak, P. (2009): Adaptive food governance. In: IHDP Update (3), 53-58.

Bourdieu, P. (1998): Praktische Vernunft: zur Theorie des Handelns. Frankfurt a.M.

- (2006): Das Recht und die Umgehung des Rechts. In: FloRian, M. and Hillebrandt, F. (eds.): Pierre Bourdieu: Neue Perspektiven für die Soziologie der Wirtschaft. Wiesbaden, 19-41.
Bourdieu, P. and Wacquant, L. J. D. (1992): The purpose of reflexive sociology (The Chicago Workshop). In: Bourdieu, P. and WACQuant, L. J. D. (eds.): An invitation to reflexive sociology. Chicago, London, 60-215.

Brass, P. (1997): Theft of an idol: text and context in the representation of collective violence. Princeton, NJ.

BütTNER, H. (2001): Wassermanagement und Ressourcenkonflikte. Eine empirische Untersuchung zur Wasserkrise und Water Harvesting in Indien aus der Perspektive sozialwissenschaftlicher Umweltforschung. Saarbrücken.

Cleaver, F. (2000): Moral ecological rationality: institutions and the management of common property resources. In: Development and Change 31 (2), 361-383. DOI: 10.1111/1467-7660.00158

- (2002): Reinventing institutions: bricolage and the social embeddedness of natural resource management. In: The European Journal of Development Research 14 (2), 11-30. DOI: 10.1080/714000425

- (2007): Understanding agency in collective action. In: Journal of Human Development, 8 (2), 223-244. DOI: $10.1080 / 14649880701371067$

Coelho, K. (2005): Unstating the public; an ethnography of reform in an urban water utility in South India. In: Mosse, D. (ed.): The aid effect: giving and governing in international development. London, 171-195.

Corbridge, S.; Williams, G.; Srivastava, M. and Véron, R. (2005): Seeing the state: governance and governmentality in India. Cambridge.

Coy, M. (2001): Institutionelle Regelungen im Konflikt um Land. Zum Stand der Diskussion. In: Geographica Helvetica 56 (1), 28-33.

de HaAn, L. and Zoomers, A. (2005): Exploring the frontier of livelihoods research. In: Development and Change 36 (1), 27-47. DOI: 10.1111/j.0012-155X.2005.00401.x

Dean, M. (2010): Governmentality. Power and rule in modern society. London.

Dörfler, T.; Graefe, O. and Müller-Mahn, D. (2003): Habitus und Feld. Anregungen für eine Neuorientierung der geographischen Entwicklungsforschung auf der Grundlage von Bourdieus "Theorie der Praxis". In: Geographica Helvetica 58 (1), 11-23.

Dupont, V. and Ramanathan, U. (2008): The courts and the squatter settlements in Delhi - Or the intervention of the judiciary in urban 'Governance'. In: BAUD, I. and DE WIT, J. (eds.): New forms of urban governance in India. Shifts, models, networks and contestations. New Delhi, 312-343.

Etzold, B. (2011): Die umkämpfte Stadt. Die alltägliche Aneignung öffentlicher Räume durch Straßenhändler in Dhaka (Bangladesch). In: Holm, A. and Gebhardt, D. (eds.): Initiativen für Recht auf Stadt: Theorie und Praxis städtischer Aneignung. Hamburg, 187-220.

- (2012): Selling in insecurity - living with violence: eviction drives against street food vendors in Dhaka and the 
informal politics of exploitation. In: HA, N. and GRAAF, $\mathrm{K}$. (eds.): Urban street vending: a global perspective on the practices and policies of a marginalized economy. New York (forthcoming).

Etzold, B.; Bohle, H.-G.; Keck, M. and Zingel, H.-P. (2009): Informality as agency - negotiating food security in Dhaka. In: Die Erde 140 (1), 1-22.

Everts, J.; M. Lahr-Kurten and Watson, M (2011): Practice matters! Geographical inquiry and theories of practice. In: Erdkunde 65 (4), 323-334. DOI: 10.3112/erdkunde.2011.04.01

Florian, M. (2006): Ökonomie als soziale Praxis. Zur wirtschaftssoziologischen Anschlussfähigkeit von Pierre Bourdieu. In: Florian, M. and Hillebrandt, F. (eds.): Pierre Bourdieu: Neue Perspektiven für die Soziologie der Wirtschaft. Wiesbaden, 73-108.

Foucault, M. (1991): Discipline and punish. The birth of prison. London.

Fuller, C. and BÉNÉï, V. (2001): The everyday state and society in modern India. London.

FüNFGELD, H. (2007): Fishing in muddy waters. Socio-environmental relations under the impact of violence in eastern Sri Lanka. Saarbrücken.

Gebhardt, H.; Glaser, R.; RadtKe, U. and Reuber, P. (2011): Geographie: Physische Geographie und Humangeographie. Heidelberg.

GHerTNER, D. A. (2010): Calculating without numbers: aesthetic governmentality in Delhi's slums. In: Economy and Society 39 (2), 185-217. DOI: 10.1080/03085141003620147

GidDEns, A. (1984): The constitution of society. Outline of the theory of structuration. Cambridge.

Glasze, G. and MattisseK, A. (eds.) (2009): Handbuch Diskurs und Raum. Theorien und Methoden für die Humangeographie sowie die sozial- und kulturwissenschaftliche Raumforschung. Bielefeld.

Goffman, E. (1974): Frame analysis. An essay on the organization of experience. Boston.

Hackenbroch, K.; Baumgart, U. and Kreibich, V. (2009): Spatiality of livelihoods: urban public space and the urban poor in Dhaka. In: Die Erde 140 (1), 47-68.

Hall, P. and Taylor, R. (1996): Political science and the three new institutionalisms. MPIFG Discussion Paper 96/6. Max-Planck-Institut für Gesellschaftsforschung. Köln.

Harriss, J.; Hunter, J. and Lewis, C. M. (1995): The new institutional economics and third world development. London.

Hasse, R. and KRÜCKEN, G. (2005): Neo-Institutionalismus. Bielefeld.

Hodgson, G. (1998): The approach of institutional economics. In: Journal of Economic Literature 36 (1), 166-192.

Hossain, S. (2011): Informal dynamics of a public utility: rationality of the scene behind a screen. In: Habitat International 35 (2), 275-285. DOI: 10.1016/j.habitatint.2010.09.003
Jepperson, R. L. (1991): Institutions, institutional effects, and institutionalism. In: Powell, W. W. and DiMaggio, P. J. (eds.): The new institutionalism in organizational analysis. Chicago, 143-163.

Jervis Read, C. (2010): Making Delhi like Paris: space and the politics of development in an East Delhi resettlement colony. Sussex.

KECK, M. (2012): Informality as borrowed security: contested food markets in Dhaka, Bangladesh. In: MACFArLAne, C. and WAibel, M. (eds.): Urban informalities. Reflections on the formal and informal. Farnham, 111-127.

Keck, M.; Etzold, B.; Bohle, H.-G. and Zingel, W.-P. (2008): Reis für die Megacity. Die Nahrungsversorgung von Dhaka zwischen globalen Risiken und lokalen Verwundbarkeiten. In: Geographische Rundschau 60 (11), 23-37.

Keck, M.; Bohle, H.-G. and Zingel, W.-P. (2012): Dealing with insecurity. Informal business relations and risk governance among food wholesalers in Dhaka, Bangladesh. In: Zeitschrift für Wirtschaftsgeographie, 56 $(1+2), 43-57$.

KNEER, G. (2008): Institutionen/Organisationen. Über die Paradoxie des Organisierens. In: Moebius, S. and ReCKWITZ, A. (eds.): Poststrukturalistische Sozialwissenschaften. Frankfurt a.M., 124-140.

KorfF, R. and Rothfuss, E. (2009): Urban revolution as catastrophe or solution? Governance of megacities in the Gobal South. In: Die Erde 140 (4), 355-370.

KRÜGER, F. (2003): Handlungsorientierte Entwicklungsforschung. Trends, Perspektiven, Defizite. In: Petermanns Geographische Mitteilungen 147 (1), 6-15.

Leach, M.; Mearns, R. and Scoones, I. (1999): Environmental entitlements: dynamics and institutions in community-based natural resource management. In: World Development 27 (2), 225-247. DOI: 10.1016/S0305750X(98)00141-7

Meyer, J.; ScotT, R. and Strang, D. (1987): Centralization, fragmentation, and school district complexity. In: Administrative Science Quarterly 32, 186-201. DOI: $10.2307 / 2393125$

MüLlER-BÖKER, U. (2001): Institutionelle Regelungen im Entwicklungsprozess. Einführung zum Themenheft. In: Geographica Helvetica 56 (1), 2-3.

Müller-Mahn, D. and Verne, J. (2010): Geographische Entwicklungsforschung - alte Probleme, neue Perspektiven? In: Geographische Rundschau 62 (10), 4-11.

Neuburger, M. (2001): Landrechte in Brasilien. Zur Bedeutung institutioneller Regelungen für Verwundbarkeit und Überlebensstrategien kleinbäuerlicher Gruppen. In: Geographica Helvetica 56 (1), 34-47.

Noe, C. (2007): Soziale Netzwerke und Gesundheit. Health Vulnerability städtischer Marginalgruppen in Colombo/ Sri Lanka. Saarbrücken. 
NorTH, D. (1990): Institutions, institutional change and economic performance. Cambridge.

Ó Tuathail, G. (1996): Critical geopolitics. The politics of writing global space. London.

Osella, F. and Osella, C. (2001): The return of King Mahabali: the politics of morality in Kerala. In: FulLer, C. and BÉNÉİ, V. (eds.): The everyday state and society in modern India. London, 137-162.

Revilla Diez, J.; Liefner, I.; Schiller, D.; Meyer, S. and BRÖMER, C. (2008): Agile firm organization and spatial division of labor in the Pearl River Delta. In: Die Erde 139 (3), 251-269.

RoDrik, D. (2004): Getting institutions right. In: CESinfo 2 (2), $10-16$

SakdapolraK, P. (2010): Orte und Räume der Health Vulnerability. Bourdieus Theorie der Praxis für die Analyse von Krankheit und Gesundheit in Megaurbanen Slums von Chennai, Südindien. Verlag für Entwicklungspolitik, Saarbrücken.

Schamp, E. W. (2000): Vernetzte Produktion. Industriegeographie aus institutioneller Perspektive. Darmstadt.

Scнмітт, T. (2011): Cultural governance as a research framework. Max Planck Institute for the Study of Religious and Ethnic Diversity. Göttingen.

ScoTt, R. W. (2008): Institutions and organizations. Ideas and interests. Thousand Oaks, London, New Delhi, Singapore.

SEARLE, J. (1995): The construction of social reality. London.

SEN, A. (1981): Poverty and famines: an essay on entitlement and deprivation. Oxford.

Senge, K. and Hellmann, K.-U. (eds.) (2006): Einführung in den Neo-Institutionalismus. Wiesbaden.

ThomI, W. (2001): Institutionenökonomische Perspektiven im Kontext der Reorganisation subnationaler Gebietskörperschaften. In: Geographica Helvetica 56 (1), 4-12.

Walgenbach, P. and Meyer, R. E. (2008): Neoinstitutionalistische Organisationstheorie. Stuttgart.

Watтs, M. (2003): Development and governmentality. In: Singapore Journal of Tropical Geography 24, 1-35.

Watts, M. and Bohle, H.-G. (1993): The space of vulnerability: the causal structure of hunger and famine. In: Progress in Human Geography 17 (1), 43-67. DOI: 10.1177/030913259301700103

WeichHart, P. (2008): Entwicklungslinien der Sozialgeographie. Von Hans Bobek bis Benno Werlen. Stuttgart.

WERLEN, B. (1997): Sozialgeographie alltäglicher Regionalisierungen. Vol. 2. Stuttgart.

Westermann, O. (2007). Poverty, access and payment for watershed hydrological services. A social feasibility study with case in Tiquipaya watershed Bolivia. Department of Environmental, Social and Spatial Changes. Roskilde.

Williamson, O. E. (1975): Markets and hierarchies, analysis and antitrust implications: a study in the economics of internal organization. New York.
Young, O.; Agrawal, A.; King, L. A.; Sand, P. H.; Underdal, A.; Wasson, M. and Schroeder, H. (2005): Science plan. Institutional dimensions of global environmental change. Bonn.

Zimmer, A. (2009): Social relations in the waste waterscapes: the case of Delhi's informal settlements. In: UGEC Viewpoints 2009, 9-12.

- (2012): Everyday governance of the waste waterscapes. A Foucauldian analysis in Delhi's informal settlements. Bonn. http://hss.ulb.uni-bonn.de/2012/2956/2956.pdf (11.09.2012)

Authors

Benjamin Etzold

Markus Keck

Dr. Patrick Sakdapolrak

Department of Geography

University of Bonn

Meckenheimer Allee 166

53115 Bonn

Germany

etzold@giub.uni-bonn.de markus.keck@geographie.uni-bonn.de sakdapolrak@giub.uni-bonn.de

Dr. Sebastian Jülich Swiss Federal Institute for Forest, Snow and Landscape Research WSL

Economics and Social Sciences Unit

Zürcherstrasse 111

8903 Birmensdorf

Switzerland

juelich@giub.uni-bonn.de

PD Dr. Thomas Schmitt Institute of Geography

University of Erlangen-Nuremberg

Kochstr. 4/4

91054 Erlangen

Germany

tschmitt@geographie.uni-erlangen.de

Anna Zimmer

Institut de Géographie

Université de Lausanne

Dorigny - Anthropole

1015 Lausanne

Switzerland

zimmera@uni-bonn.de 